Jugović, M., Ponjičan, O., Jakišić, T. (2020): The effect of rotary tiller and other machines for tillage on the soil structure aggregates. Agriculture and Forestry, 66 (1): 251-260.

DOI: 10.17707/AgricultForest.66.1.23

\author{
Milan JUGOVIĆ, Tanja JAKIŠIĆ ${ }^{1}$ Ondrej PONJIČAN ${ }^{2}$
}

\title{
THE EFFECT OF ROTARY TILLER AND OTHER MACHINES FOR TILLAGE ON THE SOIL STRUCTURE AGGREGATES
}

\section{SUMMARY}

The soil tillage is still the most complicated agro-technical measure where more than $30 \%$ of the total energy is deployed for the plant production. In the field conditions, the effect of rotary tiller as well as other machines for the supplementary treatment of the soil structure aggregates was examined in this study. The following tools and machines were used for the soil tillage: harrow (HA), rotary tiller (RT) and disc harrow (DH). In particular, it is interesting to determine the effect of rotary tiller and other machines for the soil tillage on the treatment quality as well as on the excessive attrition and making the powder structure and its degradation. By the soil tillage with different tools and machines (harrow, rotary tiller, disc harrow), there were changes in the condition of the soil aggregates, i.e. the decrease of the total content mega structural aggregates for $17.72 \%$. At the soil treatment by rotary tiller (RT), the statistically significant higher values of the structure coefficient ratio were found in regard to the tillage with the harrow as well as the disc harrow for all examined depths 1.94-2.75 and high content micro structure aggregates (diameter $<0.25 \mathrm{~mm}$ ) of $6.37 \%$. The values of volumetric mass before the tillage were in the great range from 1.06 to $1.29 \mathrm{~g} / \mathrm{cm}^{3}$ depending on the depth, while the average values of the volumentric mass (VM) of the examined soil after the treatment were in the range from 0.92 to $1.17 \mathrm{~g} / \mathrm{cm}^{3}$. By testing the ratio of volumetric mass $\left(\mathrm{X}_{\mathrm{ZM}}\right)$, the statistically significant differences were determined for the type of treatment while the measured depth has not shown the statistically significant difference. Contrary to the ratio of volumetric mass $\left(\mathrm{X}_{\mathrm{ZM}}\right)$, the ratio of structure coefficient $\left(\mathrm{X}_{\mathrm{k}}\right)$ showed a significant difference in the soil treatment by rotary tiller while the measured depth had a statistically significant differences in all three variances.

Keywords: soil tillage, rotary tiller, structure aggregates, structure coefficiant, treatment intensity, soil bulk density.

\section{INTRODUCTION}

The soil tillage is still the most complicated agro-technical measure where more than $30 \%$ of the total energy is deployed for the plant production (Marković

\footnotetext{
${ }^{1}$ Milan Jugović, (corresponding author: milan.jugovic@pof.ues.rs.ba), Tanja Jakišić, University of East Sarajevo, Faculty of Agriculture, East Sarajevo, BOSNIA AND HERZEGOVINA

${ }^{2}$ Ondrej Ponjičan, University of Novi Sad, Faculty of Agriculture, Novi Sad, SERBIA

Notes: The authors declare that they have no conflicts of interest. Authorship Form signed online.

Received:25/12/2019

Accepted:15/03/2020
} 
et al., 1995, Moteva et al., 2017). The rotary tiller (rotary cultivator) are machines which are used for shattering the lumps as well as for the attrition of soil especially in adverse conditions (hard, dry soil), backfilling and mixing with the compost soil and plant leftovers, destroying of weed (that is reproduced generatively), husking of stubble and the basic treatment, especially in the orchards, vineyards, gardens and so on. The rotary tillers as individual machines are used less because of relatively high energy consumption in relation to the tools with passive working gears (Marković et al., 1996; Bajkin, 2006).

The main reason why the rotary tillers should be used more is a significant working effectiveness, easy handling, flat soil area after the treatment and good soil attrition (Páltik et al., 2003, Salokhe and Ramalingam, 2003). During the treatment and under the effect of a certain mechanic power, the soil is shattered, torn, decomposed into pieces, aggregates, sputtered and it produces the mass made of very different aggregates, lumps and dust by size (Vučić, 1987). The analysis of the soil structure shows a figure of the content quantity of certain structural elements fractions, their reciprocal relation especially the content of micro (diameter $<0.25 \mathrm{~mm}$ ), macro (diameter $0.25-10 \mathrm{~mm}$ ) and mega aggregates (diameter $>10 \mathrm{~mm}$ ) (Ponjičan et al., 2011a).

The environment significance of the soil structure is large and it is taken for the key of the soil fertility. The structure is a regulator of water-air and thermal relations. A large venting and water-tightness of the soil is a prerequisite for a good anaerobic, biological and biochemical activity (Miljković, 1996).

Upon all types of the soil structure and from the agronomic aspect, the most favorable soil structure is the crumbly soil structure, i.e. the aggregate of $0.25-7 \mathrm{~mm}$ and in some cases even to the $10 \mathrm{~mm}$, but in the drier regions the aggregates of 0.25 to $2-3 \mathrm{~mm}$ are the most favorable from the aspect of the soil fertility (Vučić, 1987). The soil tillage quality can be effectively assessed by measuirng the physical properties of the soil. The volumic mass (soil bulk density) is especially suitable for determining the treatment effects before and after the soil treatment (Nozdrovický, 2007; Ponjičan et al., 2009).

By decreasing the excessive and unnecessary attrition, the energy used for the soil treatment would be reduced (Matjašin et al., 1988; Mitrovic et al., 2017) and the soil resources would be kept better by lower release of $\mathrm{CO}_{2}$ (Lal, 2000). The analysis of the soil structure aggregates was done for different machines' constructions of the soil tillage. The main task of examination is to determine the quality of the soil tillage by different types of machines for pre-sowing soil preparation. It is specifically interesting to determine the effect of rotary tiller and machines for the soil treatment on the quality of cultivation, but also on the excessive attiration and making of the powder structure as well as its degradation.

\section{MATERIAL AND METHODS}

The examination of the rotary tiller and machines effect for the supplementary soil tillage on the structure (aggregate composition) of the soil was carried out in the field conditions on the locality of Mokro, municipality of Pale, 
Entity of Republic of Srpska, Bosnia and Herzegovina (latitude $43^{\circ} 52^{\prime} 33^{\prime \prime}$ and longitude $18^{\circ} 36^{\prime} 26^{\prime \prime}$ ), during 2019 on the soil type dystric cambisol (brown acid soil). By the texture composition, the dystric cambisol belongs to the type of sandy loam which means that the soil has favorable physical properties because of a suitable relation of water and air in its micro and macro pores. The machines' examination for the soil tillage on the structure was carried out on the previously ploughed soil.

For the soil tillage, the following machines were used:

-harrow (HA)

-rotary tiller (RT)

-disc harrow (DH)

The depth of examination of tools and machines was $10 \mathrm{~cm}$ for the harrow and disc harrow and $15 \mathrm{~cm}$ for the rotary tiller. After the tillage, taking of the soil samples was carried in different depths (upper layer 0-5 cm, middle layer 5-10 $\mathrm{cm}$ and lower layer $10-15 \mathrm{~cm}$ ). For the needs of determining the structure coefficient, the soil samples were taken in the damaged soil of the average mass 2 $\mathrm{kg}$, by seam thickness of $5 \mathrm{~cm}$, to the depth of $20 \mathrm{~cm}$ in three repetitions. For the needs of the soil bulk density, the samples were taken in non-damaged (natural condition) by the Kopecky cylinders of $100 \mathrm{~cm}^{3}$ (Dugalić and Gajić, 2005).

The physical characteristics of the soil were determined by measuring the soil bulk density and structure coefficient (Nozdrovický, 2007; Petrovic et al., 2010; Sakin et al., 2011). For the needs of examination, the methodology and laboratory equipment ware used by the accredited Laboratory for soil of the Federal Institute for Agro-pedology. The mechanical content of the soil was determined by B-international pipet method and the texture category was determined by the triangle of Fere (Soil survey manual, 1995). The volumetric soil mass (soil bulk density) was determined by the method of Kachinsky and by the Kopecky cylinder of $100 \mathrm{~cm}^{3}$, drying on $105^{\circ} \mathrm{C}$ till the constant mass. (Hadžić et al., 2004).

The structure coefficient $(\mathrm{k})$ was determined by the method of the field dry sieving (Radojević and Petrović, 2011) and by the sieves that is used for determining the soil structure content and whose hole size is defined by the Savinov method (Hadžić et al., 2004). The structure coefficient (k) is defined as a mass relation between macro structural aggregates $(0.25-10 \mathrm{~mm})$ and sum of mega $(>10 \mathrm{~mm})$ and micro $(<0.25 \mathrm{~mm})$ structure aggregates (Šein et al., 2001; Ponjičan et al., 2012):

$$
\mathrm{k}=\frac{m_{\text {macro }}}{m_{\text {miero }}+m_{\text {mega }}}
$$

The intensity of the soil tillage was determined via the soil bulk density ratio $\left(\mathrm{X}_{\mathrm{ZM}}\right)$ and the structure coefficient ratio $\left(\mathrm{X}_{\mathrm{k}}\right)$, (Ponjičan et al., 2011a). Soil bulk density ratio $\left(\mathrm{X}_{\mathrm{ZM}}\right)$ was assessed via the relation of the volumetric mass value after the tillage $\left(\mathrm{ZM}_{\mathrm{NO}}\right)$ and the volumetric mass before the cultivation $\left(\mathrm{ZM}_{\mathrm{PO}}\right)$ by the machine for the soil tillage throughout the equation:

$$
\mathrm{X}_{\mathrm{ZM}}=\frac{Z M_{\mathrm{NO}}}{Z M_{P O}}
$$


The structure coefficient ratio $\left(\mathrm{X}_{\mathrm{k}}\right)$ was calculated via the relation of the structure coefficient value after the tillage $\left(\mathrm{k}_{\mathrm{NO}}\right)$ and the structure coefficient before the tillage $\left(\mathrm{k}_{\mathrm{PO}}\right)$ throughout the equation:

$$
\mathrm{X}_{\mathrm{k}}=\frac{k_{\text {NO }}}{k_{P O}}
$$

The assessment of the measured data was done in the licensed Excel program 2010 and IBM SPSS Statistics 21. The testing was carried out at the point of significance of $5 \%$ by F-test analysis variance and Tukey (HSD) test.

\section{RESULTS AND DISCUSSION}

The examined type of soil (brown acid soil - distric combisol) had the following percentage of the mechanical fractions: coarse sand $6.20 \%$, medium sand $52.80 \%$, powder $35.30 \%$ and clay $5.70 \%$ and it belongs to the category of sandy loam. During the tillage, the soil humidity varied in the intervals from 9.31 to $16.90 \%$ at the depth of $0-10 \mathrm{~cm}$, at the average of $12.32 \%$ at the depth of $0-5$ $\mathrm{cm}, 12.52 \%$ at the depth of $0-10 \mathrm{~cm}, 13.18 \%$ at the depth of $10-15 \mathrm{~cm}$. The examination was carried out by the optimal values of the instantaneous soil humidity where it comes to the formation of a favourable crumbly soil structure and minimal used energy for the soil tillage (Birkás, 2008a).

The reliable indicator of soil dispersion and degradation represents the presence of microstructural aggregates $<0.25 \mathrm{~mm}$ (Vučić, 1987). The mass part of microstructural aggregates was the largest on the surface soil seam $0-10 \mathrm{~cm}$ which was prepared by the machines for the surface preparation with the passive work gears of harrows and disc harrows and a classical rotary tiller.

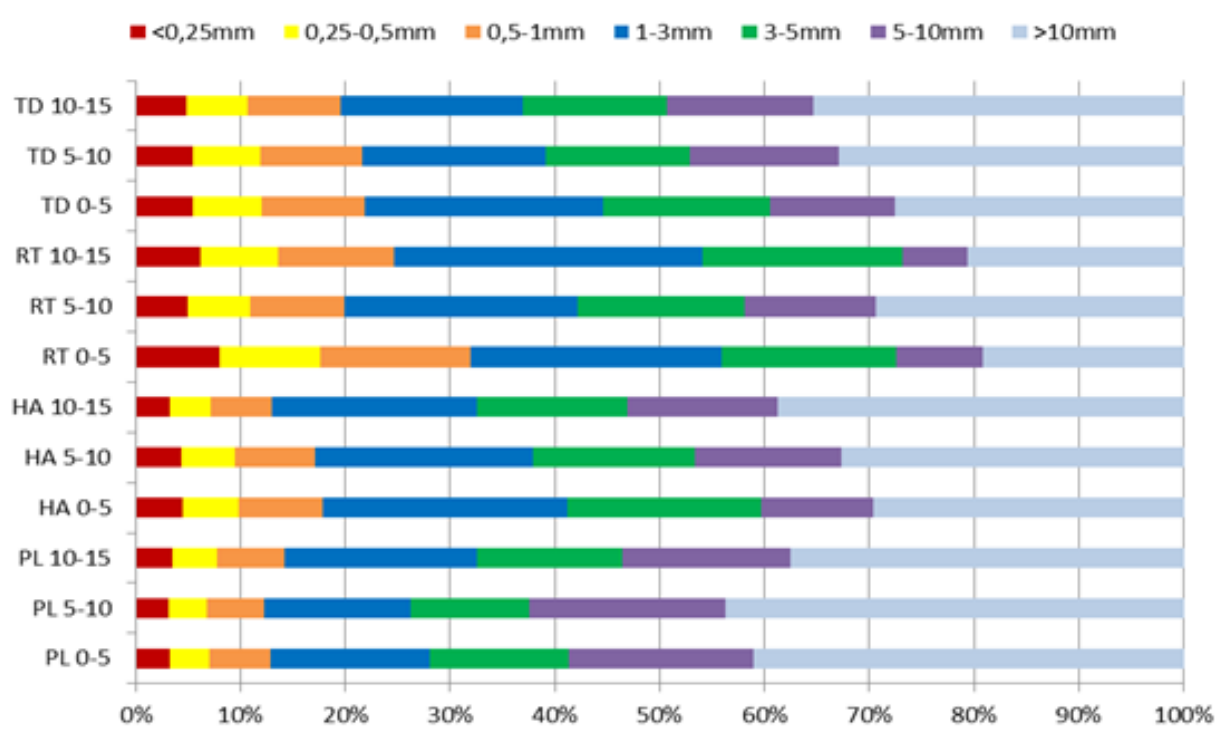

Figure 1. Percentage share of structural soil aggregates in relation to tillage type and measurement depth 
The results of structure aggregates examination through the sieving by concretely determined sieves and by the Savinova method are shown in the figure 1. The examined soil was a field. Then, the main tillage was done by a plough at the depth of $20 \mathrm{~cm}$ and then a thorough tillage was carried out by different tools and machines. A high share of coarse soil aggregates was found by the main soil tillage $(>10 \mathrm{~mm})$, approximately $40.76 \%$ at the depth of $0-15 \mathrm{~cm}$, while the average percentage share of macro aggregates $(0.25-10 \mathrm{~mm})$ was $55.95 \%$ and the share of micro aggregates $(<0.25 \mathrm{~mm})$ was $3.28 \%$ at the examined soil depth.

By the soil tillage with different tools and machines (harrow, rotary tiller, disc harrow), there were changes in the conditions of soil aggregates, i.e. the total content decrease of mega structural aggregates. Cultivating the soil by a harrow (HA) at the depth of $0-15 \mathrm{~cm}$, the percentage content of mega structural aggregates was determined in the amount of $33.65 \%$, at the depth of $0-15 \mathrm{~cm}$. The content of macro structural aggregates after the soil cultivation by a harrow was $62.34 \%$, while the content of micro structural aggregates had the value of $4.01 \%$. Unlike the harrow tillage, the treatment by a disc harrow (TD) showed the following percentage values of the structural aggregates' content at the depth of 0-15 cm: the content of mega structural aggregates $31.95 \%$, macro structural aggregates $62.80 \%$ and micro structural aggregates $5.25 \%$.

Table 1. Structure coefficient $(\mathrm{k})$ and share of micro structural aggregates $(<0.25 \mathrm{~mm})$ depending on the tillage type and measurment depth.

\begin{tabular}{|c|c|c|c|c|c|c|c|c|c|}
\hline \multicolumn{2}{|l|}{ Parameter } & \multicolumn{4}{|c|}{ Structure coefficient - k } & \multicolumn{4}{|c|}{$<0.25 \mathrm{~mm}(\%)$} \\
\hline Depth (cm) & Tillage & HA & RT & $\mathrm{TD}$ & Average & HA & RT & TD & Average \\
\hline $0-5$ & & 1.96 & 2.69 & 2.04 & $2.23 *$ & 4.47 & 7.99 & 5.45 & 5.97* \\
\hline 5-10 & & 1.71 & 1.94 & 1.61 & 1.76 & 4.29 & 4.98 & 5.41 & 4.90 \\
\hline $10-15$ & & 1.39 & 2.75 & 1.50 & 1.88 & 3.26 & 6.15 & 4.88 & 4.76 \\
\hline Average & & 1.69 & $2.46 *$ & 1.72 & & $4.01^{*}$ & $6.37 *$ & $5.25 *$ & \\
\hline
\end{tabular}

*Testing was carried out by Tukey (HSD) $\mathrm{p}<0.05$

Assessment scale of aggregate soil content per values of structure coefficient (Šein, 2001)

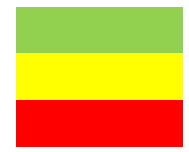

$$
\begin{aligned}
& \text { good structure } \mathrm{k}>1.50 \\
& \text { satisfactory } 0.67<\mathrm{k}<1.50 \\
& \text { unsatisfactory } \mathrm{k}<0.67
\end{aligned}
$$

The content of mega structural aggregates at the depth of $0-15 \mathrm{~cm}$ was $23.04 \%$, macro structural aggregates $70.58 \%$ and micro structural aggregates $6.37 \%$ for the soil tillage by rotary tiller (RT) and it is significantly higher from the previous two variances. A few authors state that the optimal relation of macro structural aggregates can be higher than $70 \%$, whereby the perennial examination of the relation of structural aggregates (mega: macro: micro) was increased from $35: 55: 11 \%$ to $13: 79: 8 \%$ to the benefit of macro structural aggregates which are 
the most favorable for the growth and development of cultivated cultures (Birkás, 2008b). Upon the previously mentioned statements, it can be concluded that the high quality surface soil preparation was carried out by utilizing the rotary tiller (RT) where the closest relation of structural aggregates was calculated of 23:71:6.

A detailed figure for the comparison of the soil tillage quality between the examined machines is especially determined by the structure coefficient $(\mathrm{k})$ (Ponjičan, 2008). At the tillage with the rotary tiller (RT), the statistically significant higher values of structure coefficient ration were determined in regard to the tillage by a harrow and disc harrow for all examined depths (Table 1.)

According to the assesment scale of the aggregate soil content (Šein, 2001), after the tillage with the above mentioned machines and tools in all measurement depths, an enhanced and satisfactory structure of examined soil was found. Comparing the quality of treated soil by harrow (HA) and disc harrow (TD), the statistically significant derogations of structure coefficient were not found, while the tillage with the rotary tiller (RT) had a statistically significant variances of the structure coefficient from 2.46.

In terms of depth of the examined soil profile $0-15 \mathrm{~cm}$ and by all measurement combinations, the statistically significant difference was found in the soil cultivation by the mentioned machines and tools only at the depth of 0-5 $\mathrm{cm}$. At the depth of $10-15 \mathrm{~cm}$ for rotary tiller (RT), the highest value of the structure coefficient $\mathrm{k}=2.75$ was derived and that represents unnecessary attiration of soil which negativly affects on the energetic balance of the soil tillage. At the same time, it unfavorably affects the water and air regime of soil and it comes to the increased mineralization of soil and unnecessary as well as excessive release of $\mathrm{CO}_{2}$ (Lal, 2000).

The secure indicator of dispersion and degradation of soil represents the existance of micro structural aggregates $(<0.25 \mathrm{~mm})$ (Vučić, 1987). By the increase of the soil attrition intensity comes to the growth of the micro structural aggregates content (Birkás, 2008a).

By testing the machines for soil tillage, the statistically significant difference was found for all types of cultivation, the highest content of micro structural aggregates was determined for RT 6.37\%, and the lowest for HA $4.01 \%$ (Table 1). During the soil tillage, RT on the soil surface layer $0-5 \mathrm{~cm}$, the statistically significant value of $7.99 \%$ was found for micro structural aggregates, while treating the soil with $\mathrm{HA}$ and TA the value was $4.47 \%$ and $5.45 \%$. Regarding the increase of the examined depth, i.e. measurement depth the share of micro structural aggregates decreases for all examined variances. By testing the machines for tillage on the soil surface seam of $0-5 \mathrm{~cm}$, there is a significant difference in an average value of the micro structural aggregates content of 5.97\% and that is one of the indicators of the soil dispresion and its degradation.

The volumetric mass (soil bulk density) shows the mass of absolute dry soil in the natural, undamaged state in the volume unit. Its values are used for the assessment of the soil compression level and for calculation of the total soil porosity. Before the tillage, the volumetric mass values had been in the range 
from 1.06 to $1.26 \mathrm{~g} / \mathrm{cm}^{3}$ depending on the depth, approximatelly $1.18 \mathrm{~g} / \mathrm{cm}^{3}$. According to the expectations, for the soil conditions before the tillage, higher values of volumetric mass were measured that is highly expressed at the depth of $10-15 \mathrm{~cm}$ from $1.26 \mathrm{~g} / \mathrm{cm}^{3}$. The values of volumetric mass above $1.6 \mathrm{~g} / \mathrm{cm}^{3}$ represent the barrier for the growth of root system of cultivated plants and it also comes to the water stagnation as well as to the anaerobic processes in the soil. From the stated reasons, it is necessary to decrease the number of technological processes during the soil tillage (Resulović and Čustović, 2002).

The average values of volumetric mass (VM) or soil bulk density of the examined soil for all types of tillage (Table 2) were statistically significant, while the effect of tillage at the measurment depth showed the statistically significant difference only on the soil surface layer of $0-5 \mathrm{~cm}$.

Table 2. Volumetric mass or soil bulk density (VM) depending on the trillage type and measurement depth.

\begin{tabular}{|c|c|c|c|c|c|}
\hline \multirow{2}{*}{$\begin{array}{l}\text { Parameter } \\
\text { Depth (cm) }\end{array}$} & \multicolumn{4}{|c|}{$\mathrm{VM}(\mathrm{g} / \mathrm{cm} 3)$} & \multirow{2}{*}{ Average } \\
\hline & Tillage & HA & $\mathrm{RT}$ & TD & \\
\hline $0-5$ & & 1.09 & 0.81 & 0.96 & $0.95 *$ \\
\hline $5-10$ & & 1.17 & 0.99 & 1.09 & 1.08 \\
\hline $10-15$ & & 1.25 & 0.97 & 1.09 & 1.10 \\
\hline Average & & $1.17 *$ & $0.92 *$ & $1.05^{*}$ & \\
\hline
\end{tabular}

*Testing was carried out by Tukey (HSD) $\mathrm{p}<0.05$

Similar values are stated (Ponjičan et al., 2009) who had obtained values of the volumetric mass on treated soil at the depth of $10 \mathrm{~cm}$ in his examinations, but the value was from $0.990-1.186 \mathrm{~g} / \mathrm{cm}^{3}$ depending on the pre-culture and the previous type of tillage. In the same way, Larney and Bullock (1994) state in their examinations that humidity and type of soil tillage have a significant effect on the value of volumetric mass when it comes to the decrease of the soil volumetric mass at the depth of $0-6 \mathrm{~cm}$ in the average of $0.26 \mathrm{~g} / \mathrm{cm}^{3}$.

The intensity of attrition of the soil aggregates relates the state of soil before and after the tillage and it is expressed in the soil bulk density ratio (XVM) as well as the structure coefficient ratio (Xk). The values of the volumetric mass ratio for higher intensity of attrition of soil aggregates are lower, but the values of structure coefficient ratio are higher (Figure 2). During the minimization of the energy used for the soil tillage, it is necessary to know the parameters of the attrition intensity of the soil aggregates as the soil bulk density ratio and the structure coefficient ratio (Matjašin et al., 1998; Asl and Singh, 2009; Ponjičan et al., 2011b).

By testing the soil bulk density ratio $\left(\mathrm{X}_{\mathrm{VM}}\right)$, the statistically significant differences were found for the type of tillage (Figure 2a), while the measurement depth has not shown the statistically significant difference. Contrary to the soil bulk density ratio $\left(\mathrm{X}_{\mathrm{VM}}\right)$, the structure coefficient ratio $\left(\mathrm{X}_{\mathrm{k}}\right)$ showed the 
significant difference in the soil tillage by rotary tiller (Figure 2b), while the measurement depth had a statistically significant difference in all three variances. The proven values of the structure coefficient ratio $\left(X_{k}\right)$ have shown a higher intensity of the soil aggregates attrition during the soil tillage by the rotary tiller where there is unnecessary attrition and degradation of soil at the depth of 10-15 $\mathrm{cm}$ which is accordance with the results (Ponjičan et al., 2011b).
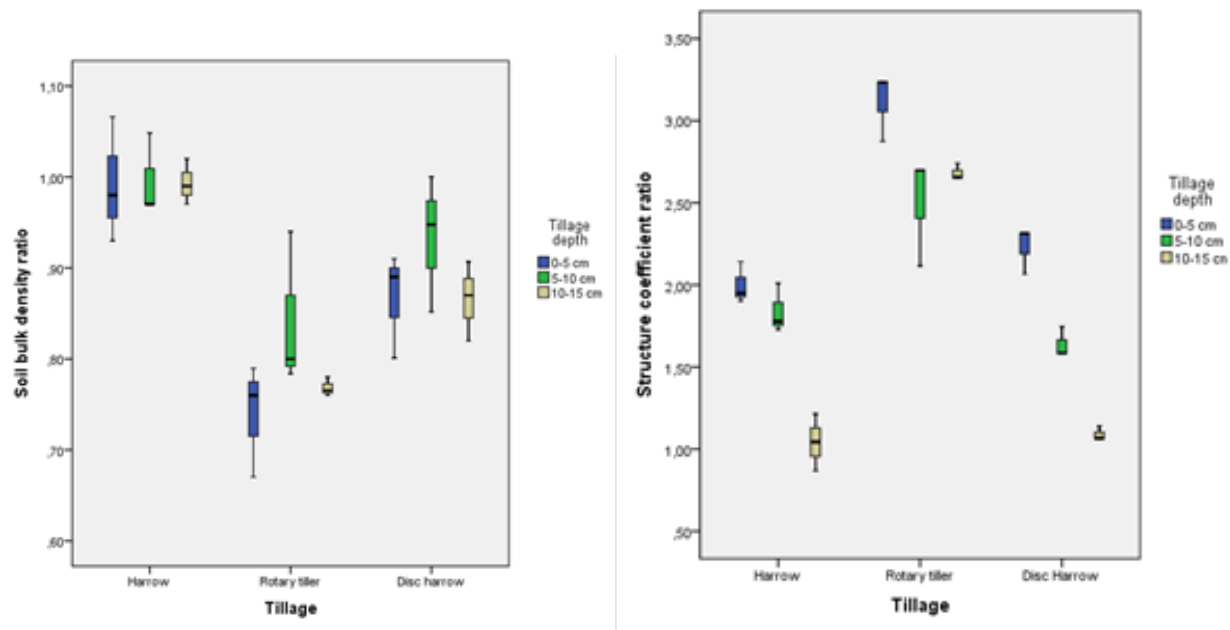

Figure 2. Tillage intensity depending on the tillage type and measurement depth: 1.soil bulk density ratio, 2.structure coefficient ratio

\section{CONCLUSIONS}

Based on the examinations carried out in the field conditions for different types of machines for pre-sowing soil preparation as well as measuring the physical properties of soil, it was found that there are clearly expressed differences in the quality of tillage and the intensity of soil attrition depending on the type of tillage and depth of examination (measurement).

The enhanced tillage quality is determined for the soil tillage by a rotary tiller, and the relation of structure aggregates of 23:71:6 with a significantly favorable form per depth. However, at the depth of 10-15 cm for rotary tiller (RT), the highest value of the structure coefficient $k=2.75$ was determined which represents unnecessary soil attrition and it affects the degradation of the soil. Before the tillage, the values of soil bulk density (VM) were in the range from 1.06 to $1.29 \mathrm{~g} / \mathrm{cm}^{3}$ depending on the depth, approximately $1.18 \mathrm{~g} / \mathrm{cm}^{3}$, and after the soil tillage the average values (VM) had the following values in the range of 0.92 (RT) to 1.17 (HA). Selecting an optimal system of the soil tillage, the energy efficiency of the soil tillage can be increased by the minimal soil degradation for the purpose of the environment protection. The quality of soil tillage and the attrition intensity of the soil aggregates must be arranged to the needs of growing plants. 


\section{ACKNOWLEDGEMENTS}

The study is the result of research financed by the Ministry of Education, Science and Technological Development of the Republic of Serbia.

\section{REFERENCES}

Asl. J. H., Singh, S. (2009). Optimization and evaluation of rotary tiller blades: Computer solution of mathematical relations. Soil Tillage Research, 106: 1-7.

Bajkin, A. (2006). Primena rotofreze u savremenoj proizvodnji povrća /Application of rotophoresis in modern vegetable production/. Savremeni povrtar, 18: 20-21.

Birkás, M. (2008a). Environmentally-sound adaptable tillage. Akadémiai Kiadó, 351.

Birkás, M., Jolánkai, M., Schmidt, R. (2008b). Environmentally-sound adaptable tillage Solutions from Hungary. In: 1st Scientific Agronomic Days. University of Agriculture, Nitra, pp. 191-194. ISBN 978805520125.

Dugalić, G., Gajić, B. (2005). Pedologija praktikum /Pedology practicum/, Agronomski Fakultet Čačak, Univerzitet u Kragujevcu ISBN 86-82107-65-1.

Hadžić, V., Belić, M., Nešić, Lj., (2004). Praktikum iz pedologije /Practicum in Pedology/. Univerzitet u Novom Sadu, Poljoprivredni fakultet, Novi Sad, Departman za ratarstvo i povrtarstvo, p. 79.

Lal, R. (2000). Soil management in developing countries. Soil Science. 165(1): 57-72.

Larney, F. J., Bullock, M.S. (1994). Influence of soil wetness at time of tillage and tillage implement on soil properties affecting wind erosion. Soil and Tillage Research 29(1):83-95, DOI:10.1016/0167-1987(94)90104-X.

Marković, D., Veljić, M., Mitrović, Z. (1995). Energetska analiza tehničkih sistema u obradi zemljišta /Energy analysis of technical systems in land cultivation/. Savremena poljoprivredna tehnika 21(3): 121-128.

Matjašin, J. I., Grincuk, I. M., Egorov, G. M. (1988). Outlay and plan rotary machines (Расчет и проектипование ротационных машин. In Russian). Agropromizdat, Moscow, Russia.

Miljković, N. (1996). Osnovi predologije /Basics of Pedology/. Univerzitet u Novom Sadu, Prirodno-matematički fakultet, Novi Sad.

Mitrović, D., Dubljević, R., Jugović, M., Markoč, M., Đorđević, N. (2017). Energy consumption and energy efficiency in lucerne ensiling, Agriculture and Forestry, 63 (3): 137-146.

Moteva, M., Kostadinov, G., Spalevic, V., Georgieva, V., Tanaskovik, V., Koleva, N. (2017). Sweet corn - conventional tillage vs. no-tillage in humid conditions, Agriculture and Forestry, 63 (1): 17-25.

Nozdrovický, L. (2007). Analiza efekata konzervacijske obrade na fizičke osobine zemljišta /Analysis of the effects of conservation tillage on the physical properties of the soil/. Savremena poljoprivredna tehnika, 33 (3-4): 263-273.

Páltik, J., Findura, P., Polc, M. (2003). Machines for plant production, soil tillage, seeding (Stroje pre rastlinnú výrobu, obrábanie pôdy, sejba. In Slovakian). Slovak University of Agriculture in Nitra, Slovakia.

Petrović, D. V., Mileusnić, Z. I., Miodragović, R. M. (2010). Correlations between statistical moments of soil aggregate size distributions. Int. Agrophys, 24: 287296.

Ponjican, O., Bajkin, A., Dimitrijevic, A., Savin, L., Tomic, M., Simikic, M., Dedovic, N., Zoranovic, M. (2011a). The effects of working parameters and tillage quality on rotary tiller specific work requirement. African Journal of Agricultural Research, 6(31): 6513-6524. 
Ponjičan, O., Bajkin, A., Jaćimović, G., Tomić, M., Savin, L., Dedović, N., Simikić, M. (2012). Tillage quality affecting physical characteristics, number of plants and carrot root yield under flat and ridge cultivation. Journal of Food, Agriculture \& Environment (JFAE), 10 (2): 304-311.

Ponjičan, O., Bajkin, A., Matić-Kekić, S., Dedović, N. (2011b). Influence of the rotary tiller construction on tillage quality and soil degradation. Proceedings of the 22nd International symposium "Safe food production", Trebinje, Bosnia and Herzegovina, 19-25 June, 2011. pp. 449-451, ISBN 978-86-7520-219-6.

Ponjičan, O., Bajkin, A., Nešić, Lj. (2008). Uticaj različitih konstrukcija mašina za formiranje gredica na strukturu zemljišta kod proizvodnje mrkve / nfluence of different constructions of machines for forming beams on soil structure in carrot production/. Časopis za procesnu tehniku i energetiku u poljoprivredi, 12(3): 164167.

Ponjičan, O., Bajkin, A., Nešić, Lj., Belić, M., Vasin, J. (2009). Uticaj obrade zemljišta rotacionom sitnilicom na promenu zapreminske mase zemljišta /Influence of tillage by rotary shredder on change in volume of soil/. Letopis naučnih radova Poljoprivrednog fakulteta, 33 (1): 175-183.

Radojević, R, Petrović, D. (2011). Zastupljenost strukturnih agregata teškog zemljišta nakon jesenje obrade/The presence of heavy soil structural aggregates after autumn tillage./. Savremena poljoprivredna tehnika 37(3): 267-276.

Resulović, H., Čustvović, H. (2002): Pedologija /Pedology/. Univerzitet u Sarajevu, Univerzitetski udžbenik, 318.

Sakin, E., Deliboran, A., Tutar, E. (2011): Bulk density of Harran plain soils in relation to other soil properties. African Journal of Agricultural. Reseach 6 (7): 1750-1757.

Salokhe, M., Ramalingan, N. (2003). Effect of rotation direction of rotary tiller on draft and power requirements in a Bangkok clay soil. Journal of Terramechanics, 39: 195-205.

Šein, B., Arhangelskaja, A., Goncarov, M., Guber, K., Pocatkova, N., Siborova, A., Umbarova, B. (2001). Field and laboratory methods appreciation physical properties and conditions of soil (Полевые и лабораторные методы исследования физических свойстед и режимоб почв. In Russian). University in Moscow, Moscow, Russia.

Vučić, N. (1987). Vodni, vazdušni i toplotni režim zemljišta /Water, air and thermal regime of soil/. Vojvođanska akademija nauka i umetnosti, Novi Sad, Srbija. 